\title{
The fungal pathogens causing diseases in pines
}

Kristina Raitelaityte் $\dot{e}^{1,2 *}$,

Arvydas Rutkauskas ${ }^{1}$,

Jana Radzijevskaja ${ }^{1}$,

Judita Žukauskiené ${ }^{1}$,

Svetlana Markovskaja ${ }^{2}$,

Algimantas Paulauskas ${ }^{1}$

${ }^{1}$ Faculty of Natural Sciences,

Vytautas Magnus University,

Vileikos St. 8, LT-44404

Kaunas, Lithuania

${ }^{2}$ Institute of Botany,

Nature Research Centre,

Žaliuju Ežeru St. 49, Lt-08406

Vilnius, Lithuania
Fungal infections are the main cause of emerging infectious diseases in forest trees. Over the past decades, the number of invasive fungal pathogens in Europe has increased exponentially. In this paper the fungal pathogens causing the most common diseases in pines like Dothistroma needle blight, brown spot needle blight, Lophodermium needle cast, Scots pine blister rust, Scleroderris canker, and Pitch canker were analyzed. These diseases cause defoliation, increase susceptibility of plants to other diseases and pests, and tree mortality can also occur. As a result, the forest industry is suffering severe economic losses. The fungi species causing infection in forest trees have been described as serious pathogens across the world including Europe, confirming a fast spread of their ranges. Knowledge of pathogens distribution, life cycle and disease symptoms are essential for the diagnostic and control of pathogenic fungi. Human-driven species expansion has increased in the last century due to the growth of international travel and trade, resulting in huge disturbance to ecosystems. Most of the plant diseases are strongly influenced by environmental conditions. Climate change has important consequences on plants, pathogens, and the interaction between them, resulting in changes on diseases epidemics. Fungal infections of plants are difficult to control because pathogens populations are variable in time, space, and genotypes. The potential damage in the future may be large, and that is why we have to be aware of the problems and discuss some possible approaches to reducing the threats.

Keywords: Dothistroma septosporum, Lecanosticta acicola, Lophodermium seditiosum, Cronartium flaccidum, Gremmeniella abietina, Fusarium circinatum

\section{INTRODUCTION}

Fungal infections are the main cause of emerging infectious diseases in forest trees. Over the past four decades, the number of invasive fungal pathogens in Europe has increased exponentially

\footnotetext{
* Corresponding author: E-mail: kristina.raitelaityte@gmail.com
}

(Desprez-Loustau et al., 2010; Santini et al., 2013). The three main factors responsible for that are geographical, climatic and socio-economic factors (2013). The countries with similar invasive pathogen numbers and species also have a similar land area, the host population, degrees of latitude, the number of eco-regions, and above-ground biomass (Santini et al., 2013). 
Today, about less than one-third of the land area of the earth is covered in forests (Sturrock et al., 2011). Forest ecosystems seem to be especially affected by climate change (Milad et al., 2011). The frequency, duration and severity of heat stress of climate change-related drought can basically alter forest composition, the structure and biogeography of forests in many regions (Allen et al., 2010). Forest plants, particularly conifers, are vulnerable to climate change because the long life expectancy of trees does not allow for quick adaptation to changes in the environmental conditions (Lindner et al., 2010).

The changes in climate will have associated consequences for biotic disturbances, such as the frequency and consequences of pest and disease outbreaks. Fungal pathogen, usually highly dependent on humidity and temperature, leading to changes in the environment may change the risk of disease (Garrett et al., 2016). Most pathogens will be able to migrate to locations where climate is suitable for their survival and reproduction at a faster rate than tree species (Sturrock et al., 2011). Therefore, it is important to keep track of the pathogen activity in neighbouring countries.
Native plant communities, woodlands, and landscapes across the world are suffering from pathogens introduced by human activities. Expansion of human-driven species increased in the last century due to the growth of international travel and trade, resulting in huge disturbance to ecosystems (Santini et al., 2013). Many of the pathogens arrive on or with living plants (Brasier, 2008).

In 2009, the causative agent of Dothistroma Needle Blight Dothistroma septosporum was found in western, southern, and central parts of Lithuania (Markovskaja et al., 2009). Lecanosticta acicola was found for the first time in the western part of Lithuania in 2009. In 20152016, this fungal pathogen was observed in new locations, on the same pine trees together with D. septosporum (Fig. 1). Lophodermium seditiosum, Cronartium flaccidum, Gremmeniella abietina are spreading all across Lithuania. Pitch canker has still not been found in Lithuania, but it is a potential threat from southern European countries.

Fungal plant infections are difficult to control because populations of pathogens are variable in time, space, and genotypes. The potential damage in the future may be

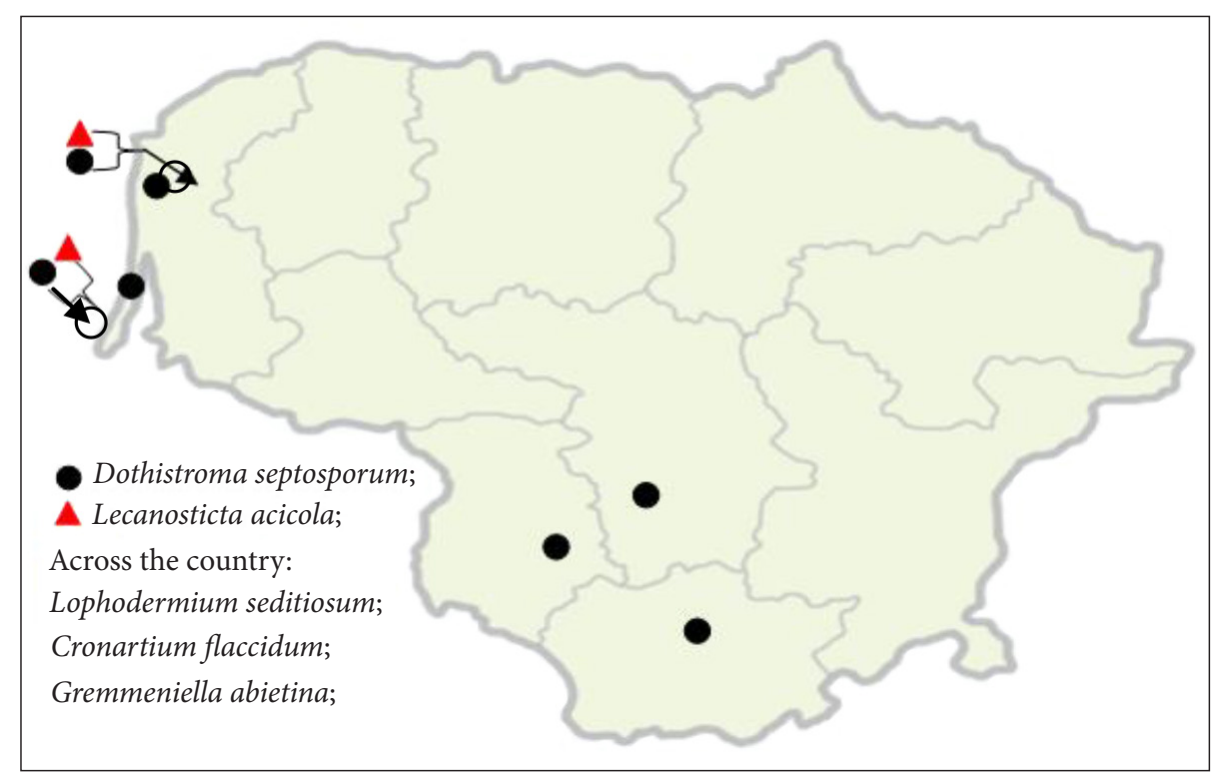

Figure. Fungal pathogens Dothistroma septosporum, Lecanosticta acicola, Lophodermium seditiosum, Cronartium flaccidum, Gremmeniella abietina found in Lithuania during 2015-2016 
large. That is why we have to be aware of the problems and discuss some possible approaches to reducing the threats. Further monitoring of diseases caused by these fungal pathogens is necessary.

\section{Dothistroma Needle Blight (DNB)}

The Dothistroma Needle Blight (DNB) disease is caused by two fungal species, Dothistroma septosporum (Dorog.) Morelet and Dothistroma pini. This disease is one of the most dangerous foliar diseases of pines (Boro et al., 2016). D. septosporum is widespread all over the world and is considered to be a globally-important forest pathogen (Chettri et al., 2013; Čahtarević, 2013; Drenkhan et al., 2013).

The first symptoms of the DNB infection is yellow spots on the needles, and later a necrotic band appears (EPPO 2015). Chlorosis begins in late summer or autumn and these characteristics remain until early spring. Usually the brown bands are encircled by a red-colour zone (Čahtarević, 2013). The needle foundation remains green for a longer period of time, and the stud ends become unviable, necrosis can occur in the central part of the stud (Markovskaja and Treigiené, 2009). When conditions favour the disease (abundant moisture and favourable temperatures between $+5^{\circ} \mathrm{C}$ to $+26^{\circ} \mathrm{C}$ ) infection severity increases (Ridout and Newcombe, 2015). Severely infected needles gradually turn completely brown, die, and fall. In less severe attacks, needle cast may be delayed for one or two years (EPPO, 2015). D. septosporum causes the needles death and, due to anticipatory defoliation, in more serious cases, influences tree death (Zhang et al., 2007).

DNB disease is observed in more than 80 species and subspecies of coniferous trees, and most commonly in the pine (EPPO, 2015). The most sensitive species is the subspecies P. nigra ssp. austriaca of the black pine (Pinus nigra). Other species of coniferous trees - European larch (Larix decidua), Douglas fir (Pseudotsuga menziesii), spruce (Picea Abies), Picea omorika (Picea Omorika), Sitka spruce (Picea sitchensis), blue spruce or silver fir (Picea pungens), Schrenk's spruce (Schrenkiana
Picea) - also are susceptible for the DNB infection (Čahtarević, 2013).

D. septosporum can be fought with copper fungicides. It is possible to use non-chemical methods of treating the damaged branches: pruning and trimming. Another alternative to chemical methods is biological control of the plants, arising from concerns about the toxicity of pesticides to the human and the environment. Planting trees with a lower susceptibility to pathogens is also proposed (McDougal et al., 2011).

\section{Brown spot needle blight}

The causative agent of Brown spot needle blight is Lecanosticta acicola (Thiimen) Sydow (Sexual stage - Mycosphaerella dearnessii ME Barr) (Suto, Ougi, 1998). In literature, it is found in various aspects of its synonyms, such as: Scirrhia acicola (Dearness) Siggers, Systremma acicola (Dearness) FA Wolf \& Barbour (Laut et al., 1966), Lecanosticta pini, Cryptosporium acicola Thum., Dothiostroma acicola (Thum) Schischkina \& Tsanava, Septoria acicola (Thum) Sacc., Oligostroma acicola Dearn (EPPO, 2015). L. acicola is known to be distributed in several continents: North America, Asia, Africa, and Europe (Adamson et al., 2015).

L. acicola fungus causes brown spots on the needles of pines of all kinds of needles. At first the resulting spots are straw-yellow, then they change to light brown, often with chestnut-brown walls. The wall of dark-brown spots occurs in autumn when the weather has cooled. Stains can also be strip-shaped, with brownish spots found on both amberyellow bands. The layers between the bands often remain green for longer periods of time (Phelps et al., 1978).

Brown spots in needles reduce the overall annual growth in young pine. It will not only inhibit growth but also cause young pine mortality. The disease also brings economic losses for Christmas tree growers in plantations of Scots pine and other varieties of suitable pine species. Pines lose their appearance due to the drop in the needles and to the brown spots (Kais and Peterson, 1986). L. acicola is included in the list of quarantine organisms in Lithu- 
ania (Lietuvos Respublikos žemès ūkio ministro issakymas Nr. 3D-264, 2016) and in A2 list of quarantine organisms in the European and Mediterranean Plant Protection Organization (EPPO 2015).

L. acicola is most often found on the mountain pine (Pinus mugo), shore pine (Pinus contorta), Aleppo pine (Pinus halepensis), butcher pine (Pinus muricata), marsh pine (Pinus palustris), seaside pine (Pinus pinaster), stone pine (Pinus pinea), radiation pine (Pinus radiata), Weymouth pine (Pinus strobus), Scots pine ( $P i$ nus sylvestris), and loblolly pine (Pinus taeda) (Čahtarević, 2013).

\section{Lophodermium needle cast}

The Lophodermium needle cast disease is caused by Lophodermium seditiosum Minter, Staley \& Millar. This fungus lives on many kinds of pine needles (Čahtarević, 2013). In Estonia, Lophodermium needle cast is the most common disease occurring on young pine trees (Pinus sylvestris) (Hanso and Drenkhan, 2007). In Balkan countries, this disease is very frequent on Scots pine (Pinus sylvestris), black pine (Pinus Niga), Aleppo pine (Pinus halepensis), mountain pine (Pinus mugo) and other pine species (Čahtarević, 2013). Rocky pine (Pinus brutia), Japanese red pine (Pinus densiflorus), mountain pine (Pinus mugo), black pine (Pinus Niga), Aleppo pine (Pinus halepensis), stone pine (Pinus pinea), Montezuma pine ( $\mathrm{Pi}$ nus montezumae) species are more likely to suffer from this disease compared with other pine species (Lazarev et al., 2007).

First symptoms of infection on needles appear from mid-August until the end of September, sometimes up to mid-October. It can be detected on young needles or on fallen needles. The infectious period lasts until next year (Čahtarević, 2013), and then symptoms appear. L. seditiosum intensively develops in AprilJune, and from May to the end of July begins a large needle drop. When the disease affects the needles, they turn brown, dry off, and fall too early. These plants become weak, their growth and overall viability are reduced. Young seedlings often die (Dabkevičius et al., 2006).
The most favourable weather conditions for the development of the disease: warm and rainy weather in summer and autumn, and mild winter (Dabkevičius et al., 2006).

Infected plants should be sprayed with fungicides three times, starting in late July, midAugust and mid-September. Strongly infected seedlings can be sprayed again in late September or early October, especially if this period is dominated by wet weather. When the seedlings are easily infected in late July, injection is unnecessary, particularly if a dry air (Rajkovic et al., 2013).

\section{Scots pine blister rust}

The causative agent of Scots pine blister rust ((Alb. \& Schw.) Wint.) Cronartium flaccidum is causing significant damage to pines in Europe and Asia. In Southern Europe it was found on a seaside pine (Pinus pinaster), mountain pine (Pinus mugo), Aleppo pine (Pinus halepensis), stone pine (Pinus pinea), Siberian dwarf pine (Pinus pumila), black pine (Pinus nigra) and other (Kaitera and Nuorteva, 2008). Scots pine blister rust is the most common on Scots pine (Pinus sylvestris), black pine (Pinus nigra), Aleppo pine (Pinus halepensis), mountain pine (Pinus mugo), seaside pine (Pinus pinaster), and stone pine (Pinus pinea) (Čahtarević, 2013).

C. flaccidum is a macrocyclic, heteroecious rust fungus with five spore stages and host-alternation. With the development of the rust fungus, the colour of the needles changes - infected needles become reddish (Čahtarević, 2013). The disease symptoms can be recognized as lesions with orange blisters (aecia) on pine stems and branches in early summer. The lesion spreads around and along the stem, eventually killing the part of the tree above the lesion by blocking the metabolism and causing a breach of necrosis (Samils et al., 2011). Treatments include cutting of infected trees in order to destroy fungal inoculum on pines where the fungus can be alive for several years (Čahtarević, 2013).

This agent often appears on the black pine (Pinus nigra), Scots pine (Pinus sylvestris), mountain pine (Pinus mugo) trees. 


\section{Scleroderris canker}

The Scleroderris canker disease is caused by the fungal pathogen Gremmeniella abietina (Lagerberg) Morelet. These pathogenic fungi are found in Central and Northern Europe, North America and Japan. G. abietina damages the coniferous forests and causes the death of trees (Romeralo et al., 2015). The fungus often appears on the black pine (Pinus nigra), Scots pine (Pinus sylvestris), mountain pine (Pinus mugo) trees.

Wet and tropical summer heat creates favourable conditions for the development of Scleroderris canker (Sikström et al., 2011). At first, the disease manifests itself as necroses forming under the bark, therefore difficult to notice. Later (most often in early spring just after snowmelt) needle tips become yellowish and then the needles turn red-brownish. The infection expands to vulnerable twigs and branches, which ultimately dry completely (Sikström et al., 2011).

The primary infection is caused by conidia, which are transported by wind and rain droplets. The infectious period begins in May and lasts until the end of November, however, a critical period of the infection is considered to be in May-June. The incubation period lasts for nine months, so if the infection occurs in the current year in June, the first visible signs appear next year in March (Čahtarević, 2013).

Studies have shown that copper fungicides (such as copper oxychloride) give the best protection from this pathogen and the best results. The treatment is sufficient twice a year, during the critical period of infection. However, such protection is feasible and economically justified only in nurseries and young plantations (Čahtarević, 2013).

\section{Pitch canker}

Pitch canker, caused by Fusarium circinatum (teleomorph Gibberella circinata), is a destructive disease of Pinus species (Iturritxa et al., 2011). Pitch canker is characterized by the development of large resinous cankers at the sites of infection in natural stands and plantations of the susceptible pine tree species (Fitza et al., 2013). It is one of the most important diseases of pine trees worldwide (Pfenning et al., 2014). F. circinatum was first recorded in North Carolina (USA) in the 1940s. The disease has also been reported in Haiti, South Africa, Japan, Korea, Mexico, Chile, Uruguay, and in Europe: Spain, France, Italy, and Portugal. Further spread of this pathogen poses a significant threat to many countries were susceptible species occur naturally or are grown extensively in plantations (Berbegal et al., 2013). In North America, main native hosts of F. circinatum are Pinus elliottii, P. palustris, . patula, $P$. radiata, $P$. taeda, $P$. virginiana and over 30 other Pinus spp., including the European and Mediterranean species $P$. halepensis, $P$. pinaster and P. sylvestris, various North American species planted in Europe such as $P$. contorta and Pinus strobus, and various Asian species (e. g., P. densiflora, P. thunbergii) (OEPP/ EPPO, 2005; Steenkamp et al., 2012). Although in Lithuania F. circinatum has not been found, there is a potential threatbecause of the country's climate and cultivated pine species.

A typical symptom of $F$. circinatum in mature trees is dead branch tips (Gordon et al., 2015). The first symptoms of the disease are wilting and discolouration of needles, followed by dieback due to the development of the resinous cankers at the sites of infection (Steenkamp et al., 2012). Wilting of needles distal to the infection site can be recognized by an accumulation of resin on the branch surface. Wilted needles lose their green colour and eventually become chlorotic, before turning red and, finally, brown. The progression of the symptoms varies with the season and age of the infected branch (Gordon et al., 2015). The pathogen can infect vegetative and reproductive structures of susceptible hosts of all ages (Steenkamp et al., 2012), but appears to grow more rapidly in succulent, current year growth than in older (Gordon et al., 2015). The fungus can affect roots, shoots, stems, flowers, cones, seed and seedlings (Steenkamp et al., 2012). It has a negative impact on the growth, violates the plant, causes the cuticle erosion, and cracks in the cell wall. Thus it allows the spread of F. circinatum (Donoso et al., 2015), causing the death of seedlings (Fitza et al., 2013). 
So far, the pathogen has shown no evidence of susceptibility to and biological control measures (Donoso et al., 2015).

\section{CONCLUSIONS}

Fungal pathogens discussed in the paper are the main cause of emerging infectious diseases in pine trees. This problem is relevant for state supervising forests institutions, which are interested in preserving the less damaged forest stands and raise healthy forest seedlings, as well as for private business owners the marketable appearance of whose trees is affected by the diseases. The main reasons of the pathogens spread are climate change and human activities, e. g., global trade and introduction of new species. Monitoring is the key to any successful control of plant diseases.

Parasitic fungal pathogens attack all species of pine which grow in Lithuania but the most susceptible are P. nigra, P. sylvestris, and P. mugo.

Lecanosticta acicola is an emerging fungal pathogen in Lithuania. Coinfection of L. acicola and Dothistroma septosporum has potential risk for pine trees, resulting in changes on diseases epidemics. Although in Lithuania F. circinatum has not been found, there is a potential threat due to the country's climate and cultivated pine species.

There exist various methods of fighting the infection-causing fungi: biological, mechanical, and chemical use of preventive-prophylactic protection. That is why continuous monitoring should be carried out. It should identify the pathogens and take the most effective way to stop the spread of the disease-causing agents, and thus reduce the losses resulting from the appearance of alien pathogens.

In the initial stages of the disease by identifying the morphology of fungal disease are complex, so for attaining facilitate early diagnosis and improve the spread of disease control measures are widely used molecular methods for pathogen identification

Received 3 August 2016 Accepted 15 November 2016

\section{References}

1. Allen CD, Macalady AK, Chenchouni H, Bachelet D, McDowell N, Vennetier M, Kitzberger T, Rigling A, Breshears DD, Hogg EH, Gonzalez P, Fensham R, Zhang Z, Castro J, Demidova N, Lim JH, Allard G, Running SW, Semerci A, Cobb N. A global overview of drought and heat-induced tree mortality reveals emerging climate change risks for forests. Forest Ecology and Management. 2010; N259: 660-84.

2. Berbegal M, Pérez-Sierra A, Armengol J, Grünwald NJ. Evidence for Multiple Introductions and Clonality in Spanish Populations of Fusarium circinatum. Population Biology. 2013; 103(8): 851-61.

3. Boro P, Lenart-Boro A, Mullett M. The distribution of Dothistroma septosporum and its mating types in Poland. Forest pathology. 2016; 10: 1-8.

4. Brasier CM. The biosecurity threat to the UK and global environment from international trade in plants. Plant Pathology. 2008; 57: 792-808.

5. Chettri P, Ehrlich KC, Cary JW, Collemare J, Cox MP, Griffiths SA, Olson MA, de Wit PJGM, Bradshaw RE. Dothistromin genes at multiple separate loci are regulated by AflR. Fungal Genetics and Biology. 2013; 51: 12-20.

6. Čahtarević N. Pine diseases in Western Balkan countries Master thesis. Mendel University in Brno Faculty of Forestry and Wood Technology Department of Forest Protection and Wildlife Management. 2013.81 p.

7. Dabkevičius Z, Vasiliauskas A, Žiogas A. Miško fitopatologija. Kaunas, 2006. 356 p.

8. Donoso A, Rodriguez V, Carrasco A, Ahumada R, Sanfuentes E, Valenzuela S. Relative expression of seven candidate genes for pathogen resistance on Pinus radiata infected with Fusarium circinatum. Physiological and Molecular Plant Pathology. 2015; 92: 42-50.

9. Drenkhan R, Hantula J, Vuorinen M, Jankovský L, Müller MM. Genetic diversity of Dothistroma septosporum in Estonia, Finland and Czech Republic. European Journal of Plant Pathology. 2013; 10(136): 71-85. 
10. EPPO Bulletin. PM 7/46 (3) Lecanosticta acicola (formerly Mycosphaerella dearnessii), Dothistroma septosporum (formerly $\mathrm{My}$ cosphaerella pini) and Dothistroma pini. 2015; 45(2): 163-82.

11. European and Mediterranean Plant Protection Organization. Data sheets on quarantine pests. Gibberella circinata. Bulletin. 2005; 35: 383-6.

12. Fitza KNE, Payn KG, Steenkamp ET, Myburg AA, Naidoo S. Chitosan application improves resistance to Fusarium circinatum in Pinus patula. South African Journal of Botany. 2013; 85: 70-8.

13. Garrett KA, Nita M, Wolf ED. De, Esker PD, Gomez-Montano L, Sparks AH. Chapter 21-Plant pathogens as indicators of climate change. Climate change (Second edition). Observed Impacts on Planet Earth. 2016. p. 325-38.

14. Gordon TR, Swett CL, Wingfield MJ. Management of Fusarium diseases affecting conifers. Crop Protection. 2015; 78: 28-39.

15. Hamelin RC, Bourassa M, Rail J, Dusabenyagasani M, Jacobi V, Laflamme G. PCR detection of Gremmeniella abietina, the causal agent of Scleroderris canker of pine. Mycol. Res. Printed in the United Kingdom. 2000; 104(5): 527-32.

16. Hanso M, Drenkhan R. Retrospective Analysis of Lophodermium seditiosum Epidemics in Estonia. Acta Silv. Lign. Hung., Spec. Edition. 2007. p. 31-45.

17. Iturritxa E, Ganley RJ, Wright J, Heppe E, Steenkamp ET, Gordon TR, Wingfield MJ. A genetically homogenous population of Fusarium circinatum causes pitch canker of Pinus radiata in the Basque Country, Spain. Fungal Biology. 2011; 115: 288-95.

18. Kaitera J, Nuorteva H. Inoculations of eight Pinus species with Cronartium and Peridermium stem rusts. Forest Ecology and Management. 2008; 255: 973-81.

19. Kais AG, Peterson GW. 54. Brown spot needle blight of pines. Diseases of Trees in the Great Plains. USDA Forest Service June 1986 General Technical Report RM-129. 1986. 161 p.

20. Lazarev V, Karadžic D, Markovic M, Pap P, Poljakovic-Pajanik L, The Most Frequent
Lophodermium spp. on Scots Pine and Austrian Pine and Their Role in the Appearance of Other Fungi on the Needles. Acta Silv. Lign. Hung., Spec. Edition. 2007. p. 53-9.

21. Lindner M, Maroschek M, Netherer S, Kremer A, Barbati A, Garcia-Gonzalo J, Seidl R, Delzon S, Corona P, Kolstrooma M, Lexer MJ, Marchetti M. Climate change impacts, adaptive capacity, and vulnerability of European forest ecosystems. Forest Ecology and Management. 2010; N259: 698-709.

22. Markovskaja S, Treigiene A. New data on invasive pathogenic fungus Dothistroma septosporum in Lithuania. Botanica Lithuanica. 2009; 15(1): 41-5.

23. McDougal R, Yang Y, Schwelm S, Stewart A, Bradshaw R. A novel GFP-based approach for screening biocontrol microorganisms in vitro against Dothistroma septosporum. Journal of Microbiological Methods. 2011; 87: 32-7.

24. Milad M, Schaich H, Bürgi M, Konold W. Climate change and nature conservation in Central European forests: A review of consequences, concepts and challenges. Forest Ecology and Management. 2011; N261: 829-43.

25. Pfenning LH, Costa SdS, Pereira de Melo M, Costa H, Ventura JA, Auer CG, Figueredo dos Santos Á. 2014. First report and characterization of Fusarium circinatum, the causal agent of pitch canker in Brazil. Tropical Plant Pathology, 39(3), p. 210-6.

26. Phelps WR, Kais AG, Nicholls TH. 1978. Brown-Spot Needle Blight of Pines. Forest Insect \& Disease Leaflet. 44.

27. Rajkovic S, Markovic M, Rakonjac L. Incubation Methods for Forecasting the Occurrence and Development of Lophodermium seditiosum Minter, Staley \& Millar on Pine. Fungicides: Showcases of Integrated Plant Disease Management from Around the World, 2013. p. 153-82.

28. Ridout M, Newcombe G. The frequency of modification of Dothistroma pine needle blight severity by fungi within the native range. Forest Ecology and Management. 2015; N 337: 153-60.

29. Romeralo C, Santamaria O, Pando V, Diez JJ. Fungal endophytes reduce necrosis length 
produced by Gremmeniella abietina in Pinus halepensis seedlings. Biological Control. 2015; 80: 30-9.

30. Samils B, Ihrmark K, Kaitera J, Stenlid J, Barklund P. New genetic markers for identifying Cronartium flaccidum and Peridermium pini and examining genetic variation within and between lesions of Scots pine blister rust in Sweden. Fungal biology. 2011; 115: 1303-11.

31. Santini A, Ghelardini L, De Pace C, DesprezLoustau ML, Capretti P, Chandelier A, Cech T, Chira D, Diamandis S, Gaitnieks T, Hantula J, Holdenrieder O, Jankovsky L, Jung T, Jurc D, Kirisits T, Kunca A, Lygis V, Malecka M, Marçais B, Schmitz S, Schumacher J, Solheim H, Solla A, Szabò I, Tsopelas P, Vannini A, Vettraino AM, Webber J, Woodward S, Stenlid J. Biogeographical patterns and determinants of invasion by forest pathogens in $\mathrm{Eu}-$ rope. New Phytologist. 2013; 197: 238-50.

32. Sikström U, Jacobson S, Pettersson F, Weslien J. Crown transparency, tree mortality and stem growth of Pinus sylvestris, and colonization of Tomicus piniperda after an outbreak of Gremmeniella abietina. Forest Ecology and Management. 2011; 262: 2108-19.

33. Steenkamp ET, Rodas CA, Kvas M, Wingfield MJ. Fusarium circinatum and pitch canker of Pinus in Colombia. Australasian Plant Pathol. 2012; 41: 483-91.

34. Sturrock RN, Frankel SJ, Brown AV, Hennon PE, Kliejunas JT, Lewis KJ, Worrall JJ, Woods AJ. Climate change and forest diseases. Plant Pathology. 2011; N60: 133-49.

35. Suto Y, Ougi D. Lecanosticta acicola, causal fungus of brown spot needle blight in Pinus thunbergii, new to Japan. Mycoscience. 1998; 39: 319 .

36. Zhang S, Schwelm A, Jin H, Collins LJ, Bradshaw RE. A fragmented aflatoxin-like gene cluster in the forest pathogen Dothistroma septosporum. Fungal Genetics and Biology. 2007; 44: 1342-54.

37. Lietuvos Respublikos Žemès Ūkio ministro ìsakymas Nr. 3D-264, 2016: Dèl kenksmingur organizmų, augalų, augalinių produktų ir kitų objektų sąrašų patvirtinimo.
Kristina Raitelaitytė, Arvydas Rutkauskas, Jana Radzijevskaja, Judita Žukauskienè, Svetlana Markovskaja, Algimantas Paulauskas

\section{GRYBINIAI PATOGENAI, SUKELIANTYS PUŠŲ LIGAS}

\section{Santrauka}

Grybinès infekcijos yra pagrindinè miškų medžių ligų priežastis. Per pastarajji dešimtmetị invazinių augalų patogenų skaičius Europoje eksponentiškai išaugo. Šioje apžvalgoje mes aptarème dažniausias grybinių patogenų sukeliamas pušų ligas: pušų raudonžiedę spyglių degligę, rudąją spyglių dèmètligę, pušų paprastąją spygliakritę, pušų liemens ir šakų rūdis, spygliuočių ūglių vẻžì, pušų věžį. Šios ligos ne tik sukelia pušų spyglių defoliaciją, bet ir sumažina atsparumą kitiems kenkejjams ir ligoms, taip pat pasitaiko medžių žūčių, dèl to miško pramonè patiria didelių ekonominių nuostolių. Svarbu tirti patogenų paplitimą, simptomus, gyvenimo ciklą ir šių pušis pažeidžiančių patogeninių rūšių galimas kontrolines priemones. Išaugus tarptautiniams augalų mainams ir suaktyvèjus žmonių kelionėms, padidejjo ir augalų sklaida, kuri turi įtakos ekosistemoms. Daugumą augalų ligų lemia aplinkos sąlygos. Ateityje klimato kaita paveiks patogenus, šeimininką ir sąveiką tarp jų, nulemdama ligos poveikio pokyčius. Šiuo metu dažniausias patogenų plitimo būdas yra prekyba gyvais augalais. Augalų patogenus sunku kontroliuoti dèl jų populiacijos kaitos laike ir erdveje, keičiasi ir jos genotipas. Potenciali žala ateityje gali būti didelè, todèl mes turime žinoti kylančias problemas ir aptarti galimus grèsmę mažinančius būdus.

Raktažodžiai: Dothistroma septosporum, Lecanosticta acicola, Lophodermium seditiosum, Cronartium flaccidum, Gremmeniella abietina, Fusarium circinatum 